\title{
THE EFFECTIVENESS OF AN EDUCATIONAL UNIT USING \\ CARDBOARD IN DEVELOPING THE AESTHETIC SENSE OF EDUCATION STUDENTS TECHNICAL KING FAISAL UNIVERSITY
}

\author{
Khaled Mohammed AL-SAUD, " Dalia Ali ABDEL MONEIM
}

Department of Art Education, Faculty of Education, King Faisal University, Saudi Arabia

\begin{abstract}
This study aimed to investigate the effectiveness of the role of an educational unit using cardboard in developing the aesthetic sense of art education students at King Faisal University. The study members consisted of (58) students from art education students in the course of forming consumed environmental materials, and the sample represented all members of society by (2) male and (3) female students in the course for the year 1438/1437 AH, the study used a set of tools represented in the cognitive test, skill test and observation tool within (20) aesthetic criteria to evaluate the final product of the cardboard material, where these tools were developed by researchers. The study resulted in the following results: The students 'achievement in the test after studying knowledge in the educational unit was high, And that there is a difference in the two averages of applying the pre and post cognitive test in favor of the post, and the results also showed that there is a difference in the averages of the application of the pre and post skill test in favor of the post, and the ratios shown by the Black Test among the average scores of the students in the cognitive test (the pre-post The percentage was acceptable, as these values showed that the students 'attainment of the knowledge and skills included in the unit, which indicates its effectiveness in students' acquisition of the knowledge and skills contained therein, which lead to a high aesthetic sense in them, and the results of the study indicated that all axes of the observation tool to judge the cartoon product The implementer and the extent of students' responses in developing the aesthetic sense is a statistically significant function, as for the gender variable The results showed that there are differences in the development of aesthetic sense caused by working with cardboard materials for the benefit of female students. The study recommended attention to the necessity of integration between the cognitive and skill framework in all the different educational curricula and the inclusion of the study plan standards and behaviors that encourage the sense of beauty, in order to narrow the gap between theory and application to increase the efficiency of the educational process.

Keywords

An Educational Unit, Cardboard, The Aesthetic Sense, Education Students, Technical King Faisal University.
\end{abstract}

\section{Introduction:}

The artistic materials used by the designer in this era have varied, and their capabilities have varied as well as their sources, some of which are extracted from nature, some of which are industrial, and the surfaces used in shaping have also varied, and thus the techniques, skills and means of implementation differed, as the plastic skill is related to the sensory properties of the material. , As the experience and the formative style with which the designer interacts with this material and volunteers to achieve his artistic work, and therefore his knowledge of the plastic technical skills of each material is considered as the ability that he controls, and with it he discovers its capacity and expressive plastic capacity, as he confirms (Ramadan, 2000) that it is Compound process from the start of the designer's selection of the material, then the performance process And implementation, which leads to the stage of aesthetic insight, which

* Corresponding author: kmsoud@kfu.edu.sa 
supports the interaction between the designer's senses and his abilities to shape using different technical skills and represent the technical skills and using them to adapt the materials visually exciting for the connoisseur through which the student's thought can be translated and read in visual and tactile forms, while we call it "the eye touches" Or what is known as the illusory texture of the eye, and John and Steven (1994, John \& Steven) refer to the distinction of natural and synthetic materials with a number of foundations and elements of the artwork, such as: Textures and fine lines, which are difficult to obtain except with accurate artistic skills with an aesthetic sense, whether it is in its shape or manipulating anthropomorphism or any other element in it, which enables the designer student to create and design works with artistic features through the use of his multiple skills. (Hamdan, 19) defines skills in general as the effectiveness of the individual through the final results, such as speed, accuracy, strength, and qualitative experiences such as rhythm, as he defined it (Arab Labor Organization Dictionary, 1990), as ease, speed and accuracy in performing work with the ability to adapt in performance to circumstances. It is defined by (Issawi, 12) as the ability to perform the integrated organization of complex complex works and the ease of adaptation to the changing conditions surrounding the work.

As for the technical skills of the learner, they cannot grow and develop by virtue of the consensus that combines the power of thinking and the hand in producing an integrated artistic painting. And it includes speed, ease and flexibility, so it requires the trainee and the teacher effort and the ability to continually practice to acquire these skills. (Al-Saud, 2011).

The educational units are one of the forms of curriculum development, as they are considered a pre-planned organization in the form of a holistic that includes the educational material, the means and accompanying educational activities and teaching methods in addition to the continuous evaluation processes that lead in their entirety to achieving the desired goals, and this needs to pass through certain experiences that lead to the acquisition of the learner. For information. Hence, experimentation through the use of different technical skills in the field of artistic works is one of the most important necessities that achieve the objectives of this field, as it focuses on developing several aspects such as the innovative aspects and control of work technology in addition to the aesthetic aspects and a sense of it. 


\section{Recommendations}

Building other units in design courses in general and technical works in particular, and experimenting with them to study their effectiveness in developing knowledge and skills to gain and develop aesthetic sense.

- Paying attention to the need for integration between the cognitive and skill framework in all the different educational curricula and the inclusion of the study plan standards and behaviors that stimulate an aesthetic feeling, in order to narrow the gap between theory and application to increase the efficiency of the educational process - Generalize learning and teaching this unit within the course of forming consumed environmental materials in the Art Education Department and departments The debate is necessary to hold training workshops by specialists for students and to make them aware of the importance of aesthetic sense in building their personalities.

\section{References}

- Abu Hatab, Fouad and Othman, Sayed and Sadiq, Amal (2000). Psychological evaluation, 4th ed., The Anglo-Egyptian Library for Printing and Publishing, Cairo.

Peter, Prince Alfons. (190). The advantages of using an educational computer when dealing with the environment in artistic formation. Art and Environment Conference The fifth scientific conference, the third axis, Helwan University.

Mohsen, Suleiman Mahmoud. (12). "The Role of Environmental Materials in Artistic Formation", Journal of Studies and Research, Faculty of Art Education, Helwan University, third issue, eleventh volume, $\mathrm{p}$.

- Hassan, Ghada Rifaat (2009). "The Effectiveness of a Teaching Unit in the Subject of Home Clothes to Develop Some Knowledge and Skills in the Light of Modern Trends", Unpublished Master Thesis, Quality Education College, Ain Shams.

- Hamdan, Muhammad Ziyad (19), Rationalizing Teaching with Modern Psychological Principles and Strategies, Modern Education Series, Jordan, Amman, House of Modern Education

- Hamida, Mazen Zaki, and Al-Shafei, Bashir Al-Shafie (2012), the effectiveness of a proposed program to improve the innovative capabilities of students of artistic works at the Faculty of Fine Arts - Al-Aqsa University - Palestine, Journal of Human Sciences / September, Volume 14 - Issue 1.

-Khairi, Bahaa El-Din. (2008). The effect of providing simultaneous and non-simultaneous education based on the Internet environment on developing the skills of accredited and independent persons on the cognitive domain of an educational unit. Computer Perspective for 
students of computer teacher preparation in Faculties of Specific Education, Master Thesis, Institute of Educational Studies - Cairo University, 2005.

Ramadan Zakia Syed (2000), intermarriage of three-dimensional materials in modern sculpture and its effect on the aesthetic values of the work of art. An experimental study, "PhD Thesis, Faculty of Art Education, Helwan University, p. 86.

- Al-Saud, Khaled Muhammad, (2011), The Effectiveness of Using Computers in Improving Aesthetics of Environmental Materials for Artistic Works of Students of the Faculty of Educational Sciences in Jordanian Universities, Journal of the Association of Arab Universities, Vol.

- Al-Saud, Khaled Muhammad, (2014) the extent of the contribution of artistic education courses related to folk crafts in preparing students for the labor market, the Saudi Ministry of Labor in cooperation with academic education, the Work Arms initiative. - Salem, Maryam (2009) Psychology of Learning, 1st Edition, Arab Renaissance, Beirut.

- Al-Slayti, Firas (2008) Teaching Strategies, Theory and Practice, 1st Edition, Amman, The Modern World of Books.

- Al-Sharif, Ahoud Abd al-Ilah (2009). "A proposed unit in home economics, development, aesthetic taste and innovation among sixth-grade students from the primary stage in the city of Makkah Al-Mukarramah." Unpublished master's thesis, College of Education, Umm Al-Qura University, Saudi Arabia

Shehata, Hassan (2001). University education and university evaluation between theory and practice, 1st Edition, Aldar Library, Arabic, Cairo.

- Al-Anani, Hanan Abdel-Hamid (2001). Child Raising Programs, 1st floor, Dar Al-Safa Amman.

- Abdel Fattah. This is my sincerity. (12). The use of computers as a distinct medium in all stages of textile printing design, the Sixth Scientific Conference, Faculty of Applied Arts Helwan University, from 7 - 2 -.

- Abdel Fattah, Fawqia (2009) Cognitive Psychology between Theory and Practice, presented by Jaber Abdel Hamid Jab, 1st Edition, Dar Al Fikr Al Arabi - Cairo.

Abdel-Rahman, Amani Abdel-Halim (2010). The development of innovative thinking among high school students using thinking skills, and its reflection on the print product, an unpublished master's thesis, Faculty of Art Education, Helwan University. Omar, Taghreed Muhammad (2009). Application of a proposed educational unit in Art Education to develop some of the skills required for female special education students "Unpublished Master Thesis, College of Education, Umm Al-Qura University, Saudi Arabia 
- Imran, Afaf Ahmad (2001) "Creating creative fields by combining the two styles of stenciling and silkscreen", Journal of Research in Art Education and Arts, Faculty of Art Education, Helwan University, Volume Three - Issue Three, July. And education, i, the house of university knowledge, and experimentation in psychology

- Essawi, Muhammad Abdel Rahman (12), Qiyas Alexandria Fadl, Yasser Muhammad (2012), the culture of processing environmental materials in the art of photography as an entrance to the development of environmental awareness and aesthetic sense of students, Faculty of Specific Education in Asyut, the 9th International Conference - Conference of Art and Culture of the Other - College Fine Arts - Minia University, II, 2, 2018.

Qutb, Muhammad Ishaq. (1994). The aesthetic concept of dealing with the material in modern sculpture and its effect on the plastic and expressive values in the works of students of the Faculty of Art Education ", PhD thesis, Faculty of Art Education - Helwan University, p. Environmental materials through the computer to develop aspects The vocabulary of forming some

Al-Kashki, Amr Ahmed. (2000). Design employment in the field of artistic works, studies and research at the scientific conference of the Arab Association for Educational Technology, Educational Technology, Cairo University, from May 3-4, 2008. In a Changing Society, Educational Technology, Studies and Research Lafta, Moussa Saadi (1990). Acquisition of manual and artistic skills, Academy of Fine Arts, Baghdad.

Al-Masad, Mahmoud (2001). Modern educational supervision, Al Israa Library, Kuwait. Muhammad, Muhammad Jalal Ali. (2012). The plastic and aesthetic capabilities of different materials and their combination to enrich the net formation. A working paper submitted to the Third International Conference (South-South Dialogue) entitled Plastic Arts and Global Changes, Assiut University, Assiut 12/13/2019, Egypt. - Muhammad, Yusri and Al-Anani, Saeed (2009). The effectiveness of teaching an educational unit in ceramics in developing some formative artistic abilities of art education students, the qualitative education conference and its role in human development in the era of globalization, the first annual scientific conference - Mansoura University, April 12-18.

- Morsi, Medhat Mohamed and Abdel-Rahman, Omaima (2012). The effectiveness of an educational unit for silkscreen printing within the "Course Designing Alex. J. Agric and Textile Printing for Development. Knowledge and skills of students of the Home Economics Department of the Faculty of Specific Education Vol. 59, No. 1, pp. 23-46, 2014 (Arabic), Res. - Mattar, Mahmoud Amin (2009), the trend towards vocational education and its relationship to some variables among secondary school students in the Gaza 10/15/2002 governorate, the 
Conference on Technical and Vocational Education in Palestine (Reality, Greetings, Ambitions),

12- Arab Labor Organization (1975), Dictionary of Labor Terminology, Arab Labor Library, Cairo, 1975. - Al-Nashif, Hady (2001). Learning and Teaching Strategies in Early Childhood, 1st Edition, Arab Thought House - Amman.

-Ara, Farhat,et al. (2011), A Study Investigating Indian Middle School Students' Ideas of Design and Designers, Journal Articles; Reports - Evaluative- Design and Technology Education, v16 n3 p62-73.

-Alias, M., Black, T. R., \& Gray, D. E. (2002). Effect of instruction on spatial visualization ability in civil engineering students. International Education Journal, 3(1).

-David Durance, (2009) cardboard furniture an exploration Survey typology of cardboard furniture material investigations. Articles .

-Eisner, Elliot W.(1998), “Forward.” In Learning in and through Art. Stephen Mark Dobb. Los Angeles: Getty Education Institute for the Arts, 1998, ix-xi.

-Feldman, E. B.(1970), Becoming Human through Art: Aesthetic Experience in the School. Englewood Cliffs, NJ: Prentice Hall,

-Friedman, M(ed) 2003, Architecture + Process: Gehry Talks, Thames \& Hudson, London John Bell \& Steven Elliot(1994). Computer Aided Design Tools,New Rider Pub.U.S.A.

-Kern, Evan J.(1987). "Antecedents of Discipline-Based Art Education: State Departments of Education Curriculum documents." In Discipline-Based Art Education Origins, Meaning, and development. ed. Ralph Smith. Urbana and Chicago, IL: University of Illinois Press, 1987, 3556.

-Kordaki, Maria, (2010). A Drawing and Multi-Representational Computer Environment for Beginners' Learning of Programming Using C: Design and Pilot Formative Evaluation, Journal Articles; Reports - Evaluative, Computers \& Education, v54 nl p69-87 Jan 2010.

-Sevigny, Maurice J.( 1987). "Discipline-Based Art Education and Teacher Education." In Discipline-Based Art Education Origins, Meaning, and Development. ed. Ralph Smith. Urbana and Chicago, IL: University of Illinois Press, 1987, 95-126.

- Noha Sayed Mohamed AFIFI, Arafa Shaker HASSAN, PRODUCTION AN EXTERNAL CLADDING UNITS USING RUBBER MOLD AND POLYESTER, International Journal of Multidisciplinary Studies in Art and Technology, Vol. 2, No. 2, 2019, pp. 1-6.

- Hadeel Muhammad Aziz Nazmi SALEM, SPECIFIC SELECTIVE MEDIA INSPIRING IDEAS OF VISUAL EXPRESSION IN THE ARTISTIC SPACE: AN APPLIED STUDY IN THE FIELD OF PAINTING FOR THE INTERPHONE AND TRANSIENT EXHIBITION 
THE EFFECTIVENESS OF AN EDUCATIONAL UNIT USING CARDBOARD IN DEVELOPING THE AESTHETIC SENSE OF EDUCATION STUDENTS TECHNICAL KING FAISAL UNIVERSITY

“THE MEDIUM SURVIVAL AND THE SURFACE IS A VISUAL PASSION”, International Journal of Multidisciplinary Studies in Art and Technology, Vol. 2, No. 2, 2019, pp. 7-11.

- Ghadeer ELMAYAH, TAKING ADVANTAGE OF THE TEXTILE INFLUENCES TO ADD THE DIMENSION OF CONCRETE TO THE WORKS OF THE ARTIST (CLAUDE MONET), International Journal of Multidisciplinary Studies in Art and Technology, Vol. 2, No. 2, 2019, pp. 12-13.

Received: February 25, 2020

Accepted: April 27, 2020 